\title{
Polymer-Cement Mortar with Quarry Waste as Sand Replacement
}

\author{
D. N. Gómez-Balbuena, ${ }^{1,2}$ T. López-Lara $\mathbb{D}^{3},^{3}$ J. B. Hernandez-Zaragoza $(\mathbb{D})^{3}$ \\ R. G. Ortiz-Mena, ${ }^{2}$ M. G. Navarro-Rojero, ${ }^{1}$ J. Horta-Rangel $\left(\mathbb{D},{ }^{3}\right.$ R. Salgado-Delgado, ${ }^{4}$ \\ V. M. Castano $\left(\mathbb{D},{ }^{5}\right.$ and E. Rojas-Gonzalez ${ }^{3}$ \\ ${ }^{1}$ CIATEQ A.C., Av. Del Retablo No. 150, Col. Constituyentes Fovissste, 76150 Santiago de Querétaro, QRO, Mexico \\ ${ }^{2}$ Instituto Tecnológico Superior de Huichapan, Domicilio conocido sn Col. El Saucillo, 42411 Huichapan, HGO, Mexico \\ ${ }^{3}$ División de Estudios de Posgrado, Facultad de Ingeniería, Universidad Autónoma de Querétaro, Cerro de las Campanas S/N, \\ Col. Niños Héroes, 76010 Santiago de Querétaro, QRO, Mexico \\ ${ }^{4}$ División de Estudios de Posgrado e Investigación, Instituto Tecnológico de Zacatepec, Calzada Tecnológico No. 27, Col. Centro, \\ 62780 Zacatepec, MOR, Mexico \\ ${ }^{5}$ Centro de Física Aplicada y Tecnología Avanzada, Universidad Nacional Autónoma de México, Boulevard Juriquilla 3001, \\ 76230 Santiago de Querétaro, QRO, Mexico
}

Correspondence should be addressed to T. López-Lara; lolte@uaq.mx

Received 31 October 2017; Revised 20 November 2017; Accepted 26 December 2017; Published 19 February 2018

Academic Editor: Antonio Gilson Barbosa de Lima

Copyright (C) 2018 D. N. Gómez-Balbuena et al. This is an open access article distributed under the Creative Commons Attribution License, which permits unrestricted use, distribution, and reproduction in any medium, provided the original work is properly cited.

\begin{abstract}
The activities of carved Quarry extraction generate problems of landscape pollution such is the case of solid waste discharged into open land dumps in central Mexico. This article presents the technological application of this solid waste in a new polymeric material with properties similar to those of a traditional mortar. It is concluded that the polymeric material uses low amounts of cement with respect to the traditional mortar, and it is elaborated with the recycled quarry as they are presented in its granulometry. The polymer used favored a low water/cement ratio (0.3) which did not allow to decrease resistance due to the fine nature of the materials (residues and cement) in addition to maintaining the workability of the material. The quarry residue was classified as silt with low plasticity and was characterized by X-ray diffraction and Fluorescence to identify $76 \%$ of $\mathrm{SiO}_{2}$, which is why it was used as a stone aggregate even though the fines content was approximately $93 \%$. The maximum compression resistance obtained at 28 days were $8 \mathrm{Mpa}$ with the polymer/solid ratios of 0.10 , water/solids of 0.30 , and quarry/solids of 0.67 . Linear equations were analyzed for more representative values with $R$ squared adjustment.
\end{abstract}

\section{Introduction}

The extraction activities of quarries (volcanic tuffs of the Riolitica type), as shown in Figure 1, generate a huge amount of solid waste that pollutes the environment and generate a lot of dust in the environment. The economic-mining activity in the region of Huichapan, Hidalgo, Mexico, represented by material banks for different industries ranks second in importance in the nonmetallic mining district of Hidalgo State. Companies extract carved rock that is marketed in the national and international market. The final products are tile for floors and facades, columns, blocks, and handcrafted pieces [1]. The volume of quarry mining production in the state of Hidalgo, Mexico, in the last 5 years averages $58 \times 106 \mathrm{~kg}$ with an annual value over $\$ 214,000$ USD [2]. It is estimated that about $40 \%$ of the production volume is wasted [3], which represents an annual volume of $23.2 \times 103 \mathrm{~kg}$ of waste. The current waste management strategy consists of unloading them in landfills in the open, regardless of the potential use that these by-products may present to other industries. Such waste is classified into two types: solid waste resulting from quarry sites or processing units and sludge originated in the processes of cutting and detailed by the water used to cool and lubricate the machines 


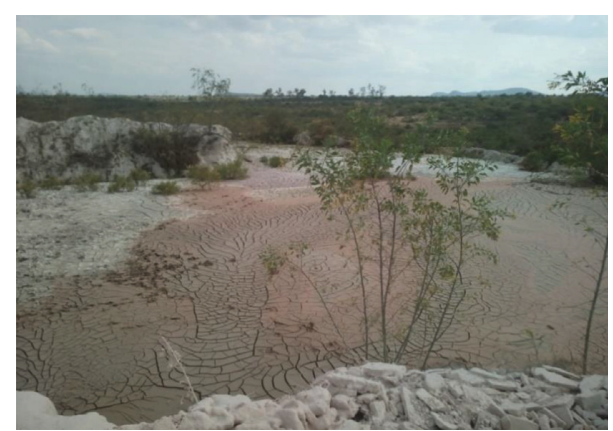

Figure 1: Accumulation of sludge (own source).

used in said processes. These sludges accumulate gradually, reducing productive space within the company, or are thrown on the sides of the roads, accumulated in unused lands, which over time be leached or dragged, and obstruct the flow of aquifers or drainages. The large quantities already accumulated of the waste demand a prompt solution, which can be sustainable and economically beneficial for the quarry industry: as indicated by Galetakis and Soultana [4], the key to the successful use of quarry dust is its adequate characterization and the development of a simple and economically viable process to convert this waste material into marketable products.

The production and dumping of solid waste has exacerbated carbon emissions and increased pollution in metropolitan cities around the world. Waste management remains a global challenge for both developed and developing countries [5]. A significant number of researchers have studied the use of quarry waste in construction offering viable solutions to this problem. The predominant proposed applications are concrete production (42\%), self-compacting concrete production (26\%), and block production (18\%) [4]. Almeida et al. [3] produced high-performance concrete using recycled stone mud and substituted 5\% sand with quarry dust improving strength and durability values in all mixtures containing less than $20 \%$ dust. Balamurugan and Perumal [6] used quarry dust in the Tamil Nadu region, India as sand replacement material for concrete production, with a maximum increase in compressive strength (19.18\%), tensile strength (21.43\%), and resistance to bending (17.8\%) with $50 \%$ replacement of sand by quarry dust. Sureshchandra et al. [7] replaced sand with quarry dust for the production of hollow concrete blocks. The blocks with replacement of $50 \%$ of sand by quarry dust had better performance than those with complete replacement of sand. Arunachalam et al. [8] used quarry powder as a light aggregate and aluminum powder as an air entraining agent for the production of lightweight concrete obtaining resistance of 3-7 MPa for mixtures with quarry dust. Adajar et al. [9] investigated the structural performance of concrete with quarry waste as a substitute for fine aggregates in a concrete mix. They formulated a model to predict the compressive strength of the mixtures made. Lohani et al. [10] replaced partially sand in concrete production. The dust content up to $30 \%$ increases the compressive strength of concrete. If the dust content exceeds $30 \%$, the resistance

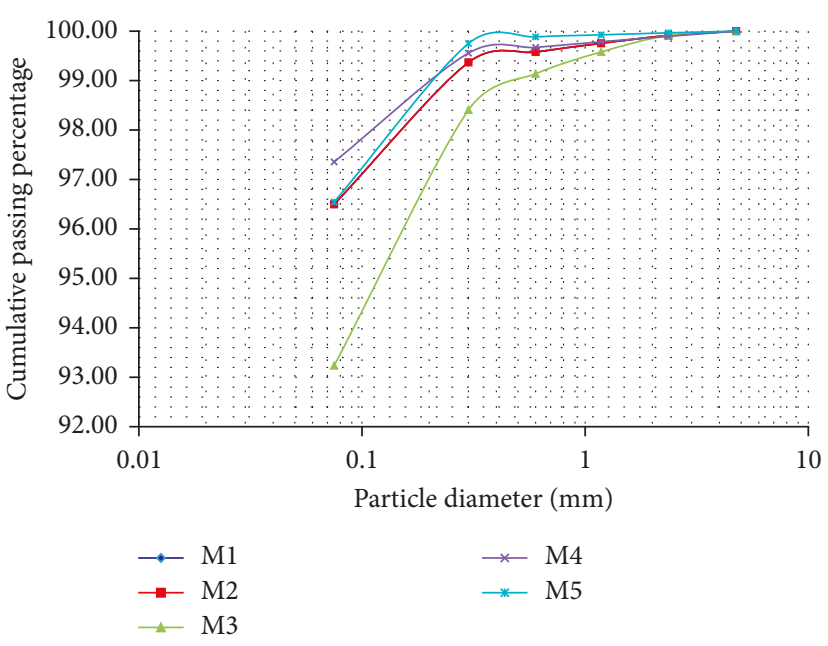

FIGURE 2: Quarry sieve analysis (own source).

gradually decreases. Safiuddin et al. [11] concluded that the addition of fine quarry waste can be used as a good substitute for sand in the production of concrete. Galetakis et al. [12] developed a laboratory method for the production of recycled quarry construction elements. Venkatakrishnaiah and Rajkumar [13] reinforced concrete with plastic waste fibers replacing natural sand with quarry dust from the Tamil Nadu region, India. The maximum resistance and best workability were with $30 \%$ of sand replacement.

Cement mortar and concrete have disadvantages such as delayed hardening, low tensile strength, shrinkage by drying, and low chemical resistance. To reduce these disadvantages, the use of polymers to modify the properties of mortar and cement has been dominant materials in the construction industry since the 1980s, which are now popularly used in advanced countries [14, 15]. Polymer-modified cement mortars are used in civil infrastructures, bridges, insulation for walls, self-leveling mortars, and concrete for fracture repair due to their excellent resistance, environmental protection and workability [2]. There is a wide variety of commercial latex polymers mostly based on elastomeric and thermoplastic polymers that form continuous films of polymer when dehydrated $[16,17]$. The latex polymers include butylbenzene latex, neoprene emulsion, polyvinyl chloride-vinylidene chloride emulsion, styrene-acrylic emulsion, styrene-butadiene carboxy latex, polyacrylate latex, and so on [18]. The dust contents that are normally handled are less than $30 \%$ in order not to affect the workability and compressive strength [19].

Polymers such as latex, redispersible polymer powders, water-soluble polymers, liquid resins, and monomers are used for the modification of mortar or cement. Latex is the most widely used additive [20]. In general, latex-type polymers are copolymer systems consisting of two or more monomers, and their total solid content corresponds to $40 \%$ or $50 \%$ of their weight [21]. The hydration of the cement precedes the process of forming thin films of polymer which leads to the monolithic comatrix phase in which the organic polymer matrix and the cement gel matrix are 


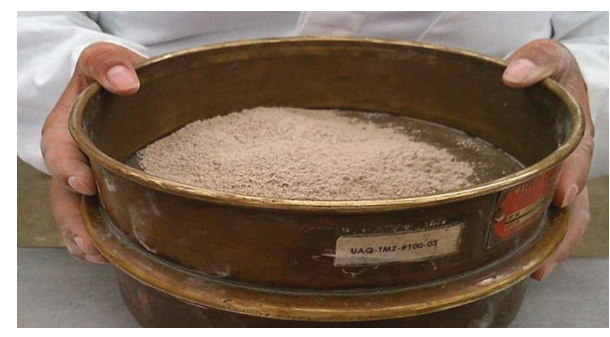

FIgURE 3: Sample of recycled Quarry (own source).

homogenized [22, 23]. Usually, a polymer/cement ratio from $5 \%$ to $15 \%$ and a water/cement ratio from $30 \%$ to $50 \%$ of the latex modified concrete depend on the workability [24].

The growth of the construction industry has led to overexploitation of natural resources such as gravel and river sand by production of concrete. So, the global trend is to use alternative materials (recycled materials) in the construction industry to make rational and sustainable use of natural materials and therefore reduce costs of construction [9].

\section{Materials and Methods}

2.1. Materials. The following materials were used:

(a) Cement CPC 30R (Ordinary Portland Cement) which complies with the characteristics established in the Mexican standard NMX-C-414-ONNCCE.

(b) Quarry waste (rhyolitic volcanic tuff) extracted from the solid waste of stone of "Jaramillo" quarries in Maney town, Huichapan Hidalgo, Mexico. It was used Quarry as a shorthand notation of Quarry waste or Quarry residue on the text.

(c) The polymer used was a synthetic latex emulsion and acrylic resins that had the specified requirements in the ASTM-1059-99 Type I Standard.

(d) Water used for the mixing and curing of the material with a $\mathrm{pH}$ value of 7 (determined by a test strip).

2.2. Methods. The methods used for the experimentation were the following:

(a) Geotechnical characterization of the waste. The field identification [25] of the material was done as well as the grain-size distribution [26], plasticity properties [27], and soil classification [28].

(b) Physical-chemical characterization of the waste. The mineralogical characterization for the determination of primary mineral species (deposit mineral associations) was done by X-ray diffraction (XRD) with Bruker D8-Advance equipment using Göebel mirror (nonflat samples), high-temperature chamber (up to $900^{\circ} \mathrm{C}$ ), X-ray generator KRISTALLOFLEX K 760-80F (power: $3000 \mathrm{~W}$, voltage: $20-60 \mathrm{kV}$, and current: 5$80 \mathrm{~mA}$ ), and a Seifert model JSO-DEBYEFLEX 2002 fitted with a copper cathode and a nickel filter.

(c) Analysis and comparison of grain-size distributions [26] of different types of sands as well as their

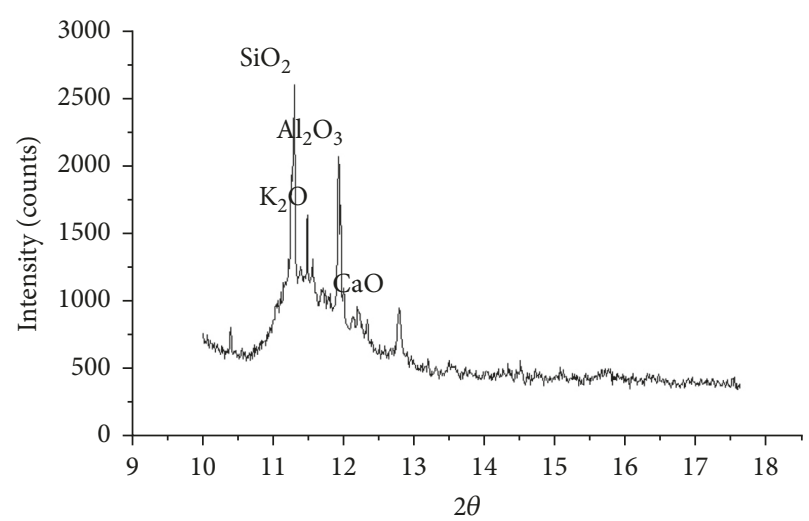

FIgURE 4: X-ray diffraction spectrum of the Quarry waste used (own source).

mineralogical composition determined by X-ray diffraction and fluorescence.

(d) Compression test according to [29]. The compression strength of the mixtures was determined according the ASTM C39/C39M-2016b Standard Test Method for Compressive Strength of cylindrical concrete specimens at 3, 7, 14, and 28 days. For the compression test [29], a hydraulic press of 20 tons was used, with pressure sensor WIKA model A10, from 0 to 200 bar and analog output from 0 to $10 \mathrm{Vdc}$, Fluke Brand Model 115 multimeter.

\section{Results and Discussion}

3.1. Geotechnical Characterization of the Waste. According to the field identification, grain-size distribution analysis [26], determination of the plasticity limits (liquid and plastic) [27], and classification of soils [28], the following results were obtained:

From the field identification, the recycled quarry residues were materials with low tenacity and slow dilatation and had very low resistance in the dry state. No odor was perceived. The material color was brown to white in light tones. From the classification of soils, the material was a rock powder with little content of slightly plastic inorganic clay located below the " $\mathrm{A}$ " line in the plasticity chart. Figure 2 shows the grain-size distribution analysis curves of five waste samples [26]; the data showed that more than $90 \%$ of the material passed the 200 mesh. The liquid limit was $24.98 \%$, and plastic limit was $21.25 \%$. Plastic index was $4 \%$ on average. So, the classification of soil [28] was ML (inorganic low-compressibility lime, material whose particles have certain cohesion between them in the presence of water). Based on [24], the waste Quarry has the following important engineering properties when the material is compacted and saturated: permeability from semipermeable to impermeable, acceptable shear strength, medium compressibility, and acceptable workability as a construction material. Figure 3 shows the waste Quarry used.

3.2. Geological and Physical-Chemical Characterization of the Quarry Waste. The geological analysis of the waste [30] 
TABLe 1: \% of chemical composition of recycled Quarry.

\begin{tabular}{lccccccccccc}
\hline Chemical composition of Quarry & $\mathrm{SiO}_{2}$ & $\mathrm{Al}_{2} \mathrm{O}_{3}$ & $\mathrm{~K}_{2} \mathrm{O}$ & $\mathrm{CaO}$ & $\mathrm{Na}_{2} \mathrm{O}$ & $\mathrm{TiO}_{2}$ & $\mathrm{SO}_{3}$ & $\mathrm{MgO}$ & $\mathrm{Cl}_{2}$ & $\mathrm{P}_{2} \mathrm{O}_{3}$ \\
\hline Normalized means & 75.958 & 10.796 & 8.5099 & 2.4279 & 0.9631 & 0.4791 & 0.323 & 0.1486 & 0.1144 & 0.0567 \\
\hline
\end{tabular}

TABLE 2: \% of chemical composition of recycled Quarry.

\begin{tabular}{lccccccccc}
\hline Chemical composition of Quarry & $\mathrm{BaO}$ & $\mathrm{ZrO}_{2}$ & $\mathrm{Rb}_{2} \mathrm{O}$ & $\mathrm{ZnO}$ & $\mathrm{SrO}$ & $\mathrm{Y}_{2} \mathrm{O}_{3}$ & $\mathrm{CeO}_{2}$ & $\mathrm{Ga}_{2} \mathrm{O}_{3}$ & $\mathrm{Nb}_{2} \mathrm{O}_{3}$ \\
\hline Normalized means & 0.0541 & 0.0536 & 0.0307 & 0.0256 & 0.0209 & 0.0172 & 0.0169 & 0.0023 & 0.0021 \\
\hline
\end{tabular}

indicated that the geology of the Huichapan caldera corresponds to an upper ignimbrite with columnar fracture and partially welded. Ignimbrite contains lithic fragments of andesite, quartz, and feldspar in a vitreous matrix (lightly crushed vitreous fragments).

The qualitative analysis by means of X-ray diffraction of Quarry dust is observed in Figure 4. The major component in the Quarry waste was silicon dioxide.

Tables 1 and 2 show the results of the X-ray fluorescence analysis of the recycled Quarry (results expressed as a percentage of the compounds present in the waste). Tables 1 and 2 show the following: (1) Silicon dioxide is the major component and is present in 76\%. According to [31], the silicates are the most important component of the hydrated cement and the cause of their resistance. Silicon dioxide compound presents a significant difference between the Quarry waste and the cement, since the latter requires only $25 \%$ of content. Based on [32], this excess of silicon dioxide will favor the reduction of the porosity of the mixture to improve the interface of the Portland cement paste adhered to the aggregate. Therefore, the strength and compactness of the final product are increased. (2) $\mathrm{CaO}$ is the compound that provides the greatest resistance to cement [31]: in this study, the Quarry waste has much lower amounts than cement, $2.4 \%$ and $67 \%$, respectively. It would be expected that mixtures containing high percentages of Quarry waste present low resistances. (3) Alkaline compounds (such as $\mathrm{Na}_{2} \mathrm{O}$ ) cause disintegration of concrete and affect the rate of increase of cement strength [31]. $\mathrm{Na}_{2} \mathrm{O}$ compound $(0.96 \%)$ in the Quarry waste is within of the allowable range of 0.2 to $1.3 \%$ of the cement. (4) Magnesium oxide (MgO) [31] is a substance that often accompanies calcium oxide. $\mathrm{MgO}$ is not combined during the cooking process of Portland cement and therefore it does not form hydraulic components but remains as free $\mathrm{MgO} . \mathrm{MgO}$ is similar to lime. So water hydrates and increases the volume of $\mathrm{MgO}$. A high percentage of $\mathrm{MgO}$ implies the risk of expansion [33]. Expansion by $\mathrm{MgO}$ is more dangerous because it appears very slowly over the years. For this reason, the cement standard stipulates a maximum limit of $5 \%$ for the $\mathrm{MgO}$ content. In this study, the $\mathrm{MgO}$ content was favorable with only $0.15 \%$. The gray-green color of Portland cement is due to $\mathrm{MgO}$ [31].

\subsection{Analysis and Comparison of Grain-Size Distributions and} Mineralogical Composition of Sands. Figure 5 shows a comparative analysis of the chemical compositions obtained by X-ray diffraction of the Quarry, river sands of Boye-HUI-53

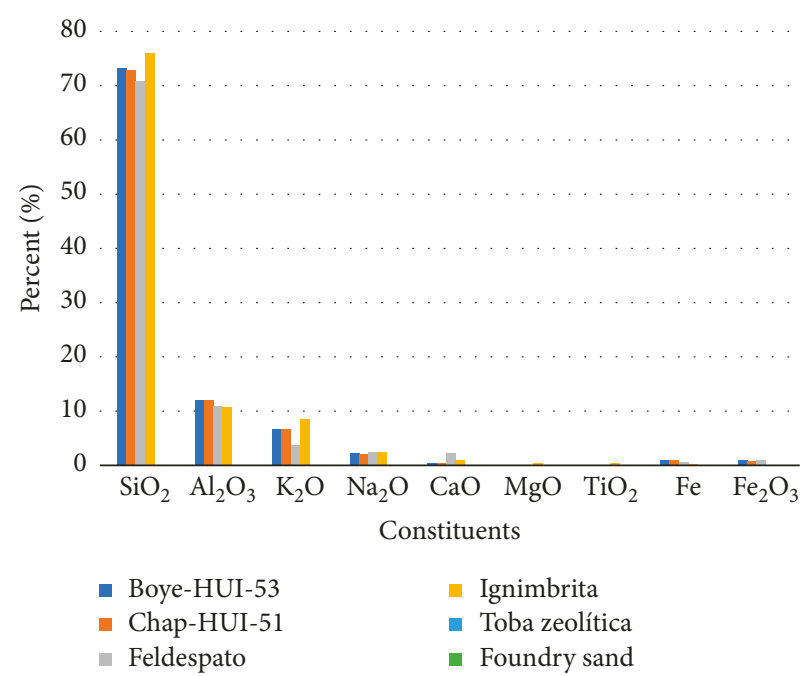

FIgURE 5: Chemical composition for different sands and ignimbrita (own source).

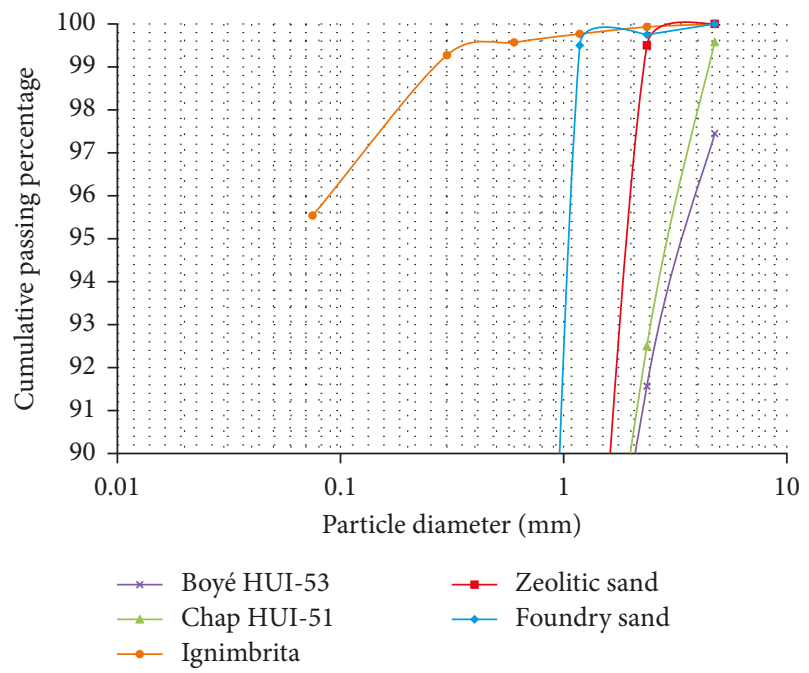

FIgURE 6: Sieve analysis for different sands [24, 29] (own source).

and Chap-HUI-51 [2], feldspathic sand, zeolitic tuff sand, and silica sand foundry. The river sands are from regions near the place where the ignimbrite (Quarry waste) was extracted. Feldspathic sand is used in the ceramics industry [34] and zeolitic tuff sand is used for lining mortar [35]. High-quality silica sand foundry is a by-product generated by the ferrous and nonferrous metal foundry [36]. The 
TABLE 3: Quantities in grams for the different concrete mixtures (own source).

\begin{tabular}{|c|c|c|c|c|c|c|c|}
\hline MIX & Cement (g) & Quarry (g) & Water (g) & Polymer (g) & Quarry/solids & Water/solids & Polymer/solids \\
\hline M1 & \multirow{12}{*}{100} & \multirow{6}{*}{200} & \multirow{3}{*}{90} & 30 & 0.67 & 0.30 & 0.10 \\
\hline M2 & & & & 45 & 0.67 & 0.30 & 0.15 \\
\hline M3 & & & & 60 & 0.67 & 0.30 & 0.20 \\
\hline M4 & & & \multirow{3}{*}{120} & 30 & 0.67 & 0.40 & 0.10 \\
\hline M5 & & & & 45 & 0.67 & 0.40 & 0.15 \\
\hline M6 & & & & 60 & 0.67 & 0.40 & 0.20 \\
\hline M7 & & \multirow{6}{*}{300} & \multirow{4}{*}{120} & 40 & 0.75 & 0.30 & 0.10 \\
\hline M8 & & & & 60 & 0.75 & 0.30 & 0.15 \\
\hline M9 & & & & 80 & 0.75 & 0.30 & 0.20 \\
\hline M10 & & & & 40 & 0.75 & 0.40 & 0.10 \\
\hline M11 & & & \multirow[t]{2}{*}{160} & 60 & 0.75 & 0.40 & 0.15 \\
\hline M12 & & & & 80 & 0.75 & 0.40 & 0.20 \\
\hline
\end{tabular}

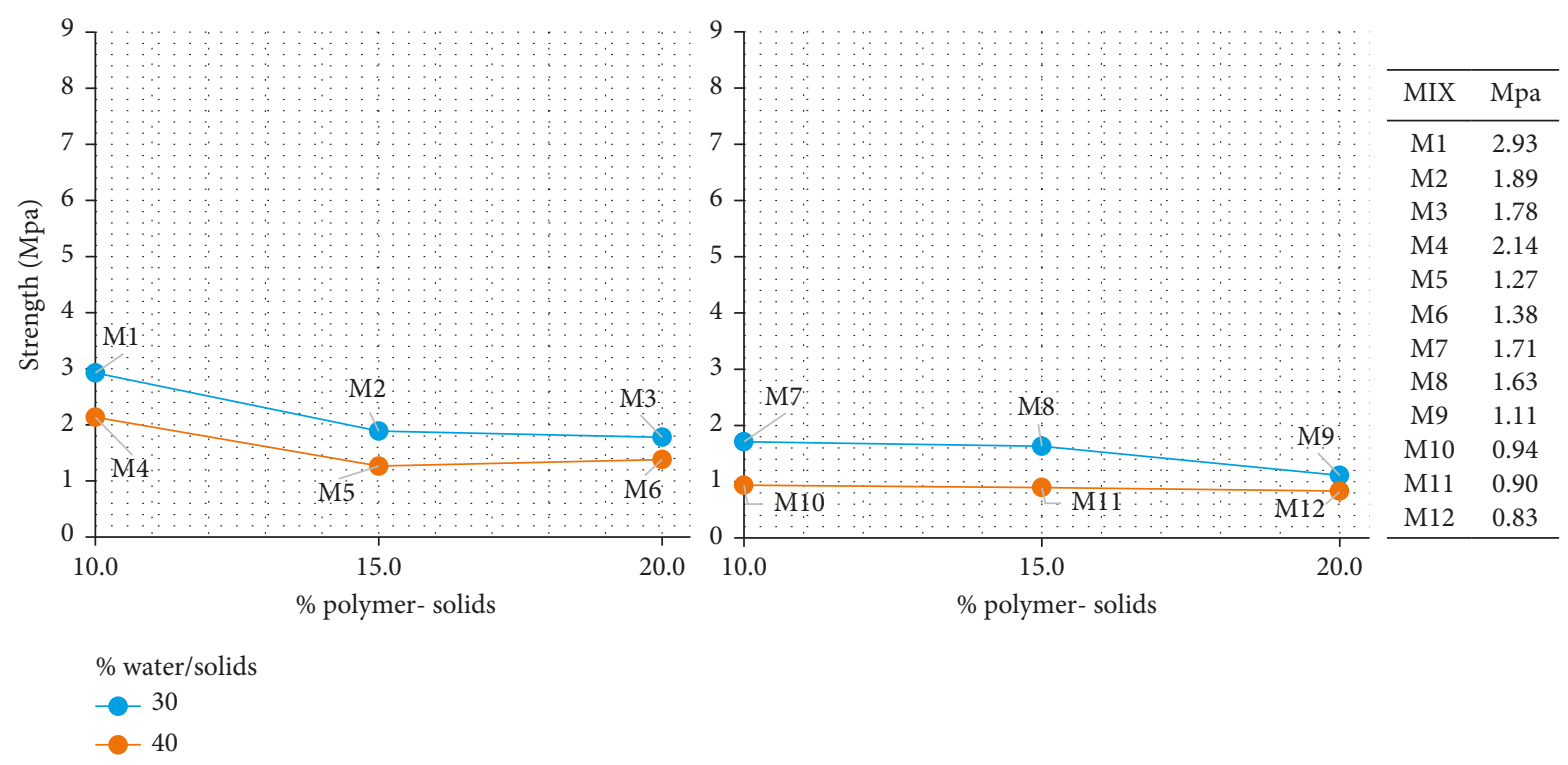

FIgURe 7: Compression resistance at 3 days (own source).

results showed that the mineralogical compositions of all the sands and quarries are very similar.

A comparative grain-size analysis distribution [26] corresponding to zeolitic sand [35], foundry sand [36], ignimbrite rhyolitic, and 2 types of sands for construction in the regions of Chapantongo and Boyé in Hidalgo México was reported in Figure 6.

From the comparison of the sands (Figure 6), it was observed that the sands of Chapantongo and Boyé had similar grain-size distributions with average grain size of $2.36 \mathrm{~mm}$ passing both $80 \%$ content by mesh number 16 . Chapantongo sand was slightly thinner since $39 \%$ of the material analyzed passed the 50 mesh (grain size of $0.3 \mathrm{~mm}$ ) compared to $26 \%$ of the Boyé sand that passed the same mesh. The zeolitic sand and foundry sand had a finer granulometry whose aggregates in both cases passed in $60 \%$ the 30 mesh $(0.60 \mathrm{~mm})$. The ignimbrite curve showed a very smooth slope which indicates that their grain size differs significantly from the other sands. More than $95 \%$ of the ignimbrite passed the 200 mesh $(0.075 \mathrm{~mm})$.

Based on the comparative analysis of the physicochemical characterization of the Quarry waste and various sands, it was observed that it could be viable to replace the sand by a fine aggregate by the similarity of chemical composition. From the grain-size distributions curves, it was observed that the sands had more uniform dimensions (sandy aggregates with very few fines). On the other hand, the ignimbrite was a fine soil, and therefore the mechanical behavior can be less favorable. However, derived from the similarity in chemical composition and granulometry between the Quarry and various sands studied, the feasibility of replacing $100 \%$ of sand as a fine aggregate by the ignimbrite can be used in the production of mortars and concretes. Based on [37], this substitution 

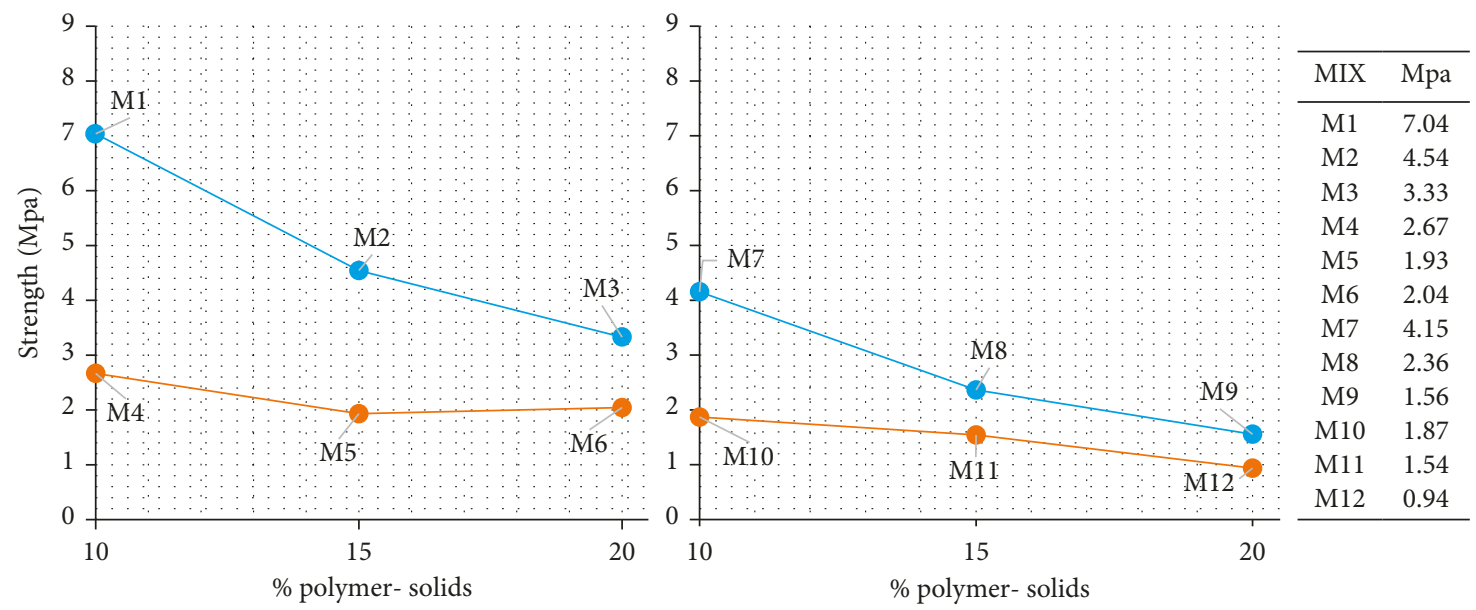

$\%$ water/solids

- 30

$-40$

Figure 8: Compression resistance at 7 days (own source).
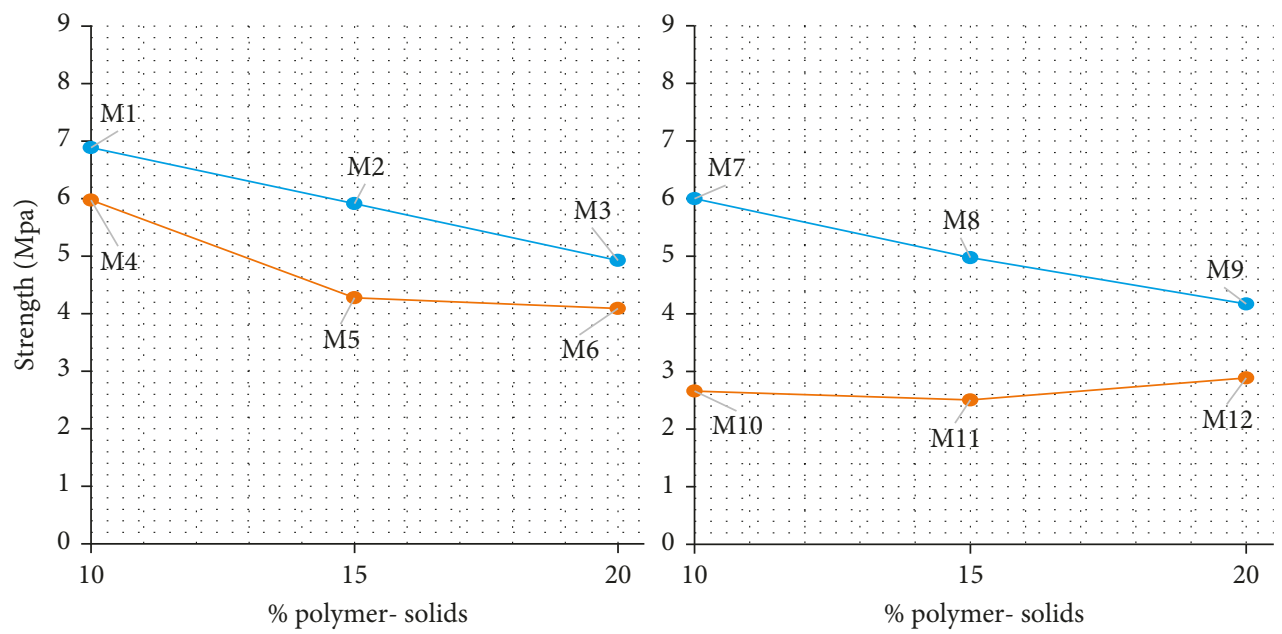

\begin{tabular}{cc}
\hline MIX & Mpa \\
\hline M1 & 6.89 \\
M2 & 5.91 \\
M3 & 4.93 \\
M4 & 5.98 \\
M5 & 4.28 \\
M6 & 4.09 \\
M7 & 6.01 \\
M8 & 4.98 \\
M9 & 4.17 \\
M10 & 2.66 \\
M11 & 2.51 \\
M12 & 2.89 \\
\hline
\end{tabular}

$\%$ water/solids

- 30

- 40

Figure 9: Compression resistance at 14 days (own source).

generates in the products increased tenacity and impact resistance and reduced shrinkage by drying and cracking in its hardened state.

3.4. Compression Test Analysis. Compressive strength testing was undertaken at $3,7,14$, and 28 days of age upon $0.051 \mathrm{~m}$ diameter and $0.102 \mathrm{~m}$ length cylindrical specimens, maintaining a length to diameter ratio of 2, according to [38]. 12 mixtures were elaborated of different proportions based on the following premises: (1) use the largest amount of quarry dust; (2) use the least amount of water without affecting aspects such as the workability of the sample and without using additives such as superplasticizers; and (3) use the least amount of polymer. Table 3 shows the 12 proportions for the different samples considered for the present study. The samples were numbered according to the MIX column, being M1 the sample number one and so on. The columns cement, quarry, water, and polymer show the quantities used in grams for each mixture. The amount of $100 \mathrm{~g}$ of cement was constant in all the mixtures, adding double amount of the Quarry $(200 \mathrm{~g})$ for the mixtures M1 to M6 and the triple amount of Quarry ( $300 \mathrm{~g}$ ) for the mixtures M7 to M12. In the Quarry/solids column, the high content of ignimbrite residue is highlighted with respect to the quantity of 

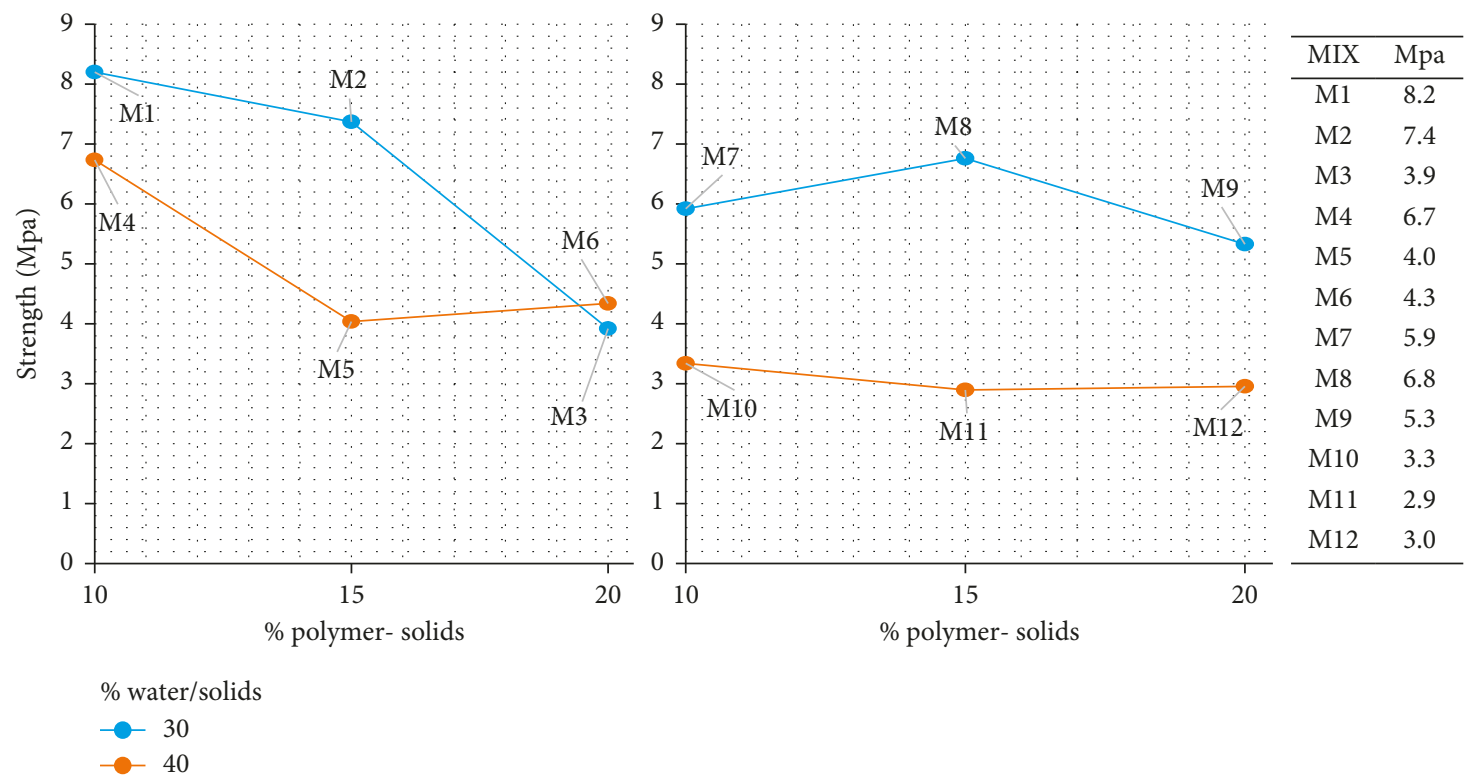

FIgURE 10: Compression resistance at 28 days (own source).

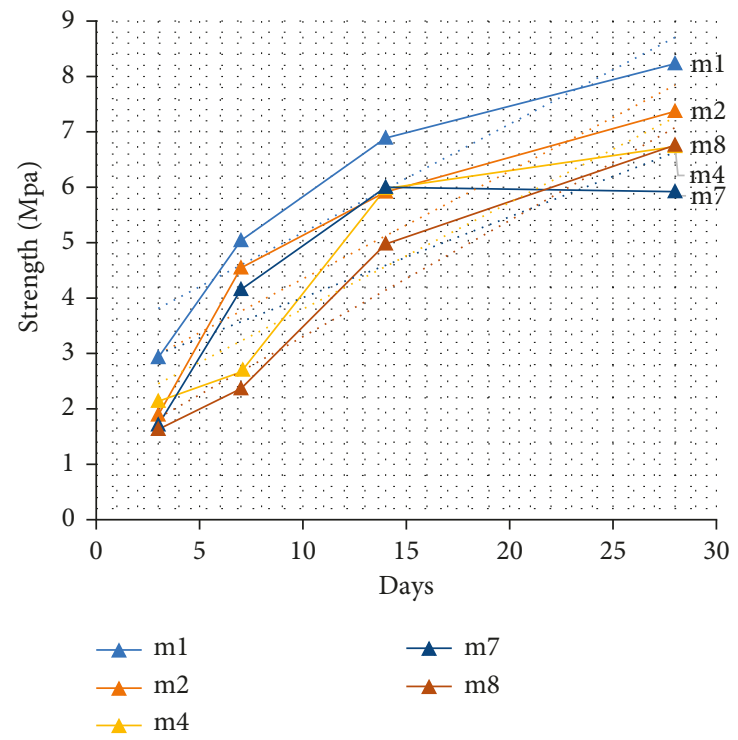

FIGURE 11: Most representative values and trend lines (own source).

solids handling values of 0.67 and 0.75 (ratios calculated by (2)). The amounts of 90,120 , and $160 \mathrm{~g}$ of water used in the mixtures correspond to ratios of 0.3 and 0.4 of water with respect to the amount of solids (indicated in the water/solids column and calculated by (3)). The polymer was mixed in ratios of $0.10,0.15$, and 0.20 with respect to the amount of solids (indicated in the column polymer/solids and calculated by (4)). The abovementioned solids are indicated as the sum of cement and Quarry in (1).

Solids = grams quarry + grams cement,

$$
\frac{\text { Quarry ratio }}{\text { Solids ratio }}=\frac{\text { (quarry grams) }}{\text { (quarry grams }+ \text { cement grams) }},
$$

Water ratio solids $=\frac{(\text { grams of water })}{(\text { grams of quarry }+ \text { grams of cement })}$,

$\frac{\text { Polymer ratio }}{\text { Solids ratio }}=\frac{(\text { polymer grams })}{(\text { grams of quarry }+ \text { grams cement })}$. 
TABle 4: Linear equations and $R$-square value for most representative mixtures (own source).

\begin{tabular}{lc}
\hline Linear equations & $R$ square value \\
\hline$y 1=0.1957 x+3.2262 ;$ & $R^{2}=0.8707$ \\
$y 2=0.1943 x+2.4037 ;$ & $R^{2}=0.8368$ \\
$y 4=0.1923 x+1.8775 ;$ & $R^{2}=0.8339$ \\
$y 7=0.1458 x+2.5507 ;$ & $R^{2}=0.6328$ \\
$y 8=0.2096 x+1.2071 ;$ & $R^{2}=0.9445$ \\
\hline
\end{tabular}

For compression tests according to [29] at 3, 7, 14, and 28 days, the reported results are the average of three compression tests of each of the 12 mixtures performed. The load was applied axially and continuously until failure of the specimen recording the maximum load applied and the type of fracture according to [29]. At three days, the highest resistance of $3 \mathrm{MPa}$ occurred in the M1 mixture with quarry/solids ratio of 0.67 , water/solids of 0.30 , and polymer/solids of 0.10 . The results are shown in Figure 7.

Figure 8 shows results obtained at 7 days highlighting M1 and M7 with respect to the resistance measured at 3 days with increases of $130 \%$ and $142 \%$ reaching 7 and $4 \mathrm{Mpa}$, respectively. The results at 14 days are observed in Figure 9 highlighting M4 that increased the resistance obtained to 7 days from $2.6 \mathrm{Mpa}$ up to $6 \mathrm{MPa}$ in 14 days with a water/solids ratio of 0.4 . Another significant resistance increase occurred in M7 that reached $4 \mathrm{Mpa}$ with low water/solids ratios of 0.3 and polymer/solids of 0.1 but significant Quarry/solids ratio of 0.75 .

Figure 10 shows that $\mathrm{M} 1$ reached the highest resistance at 28 days in the order of $8 \mathrm{Mpa}$ and M2 shows resistance close to M1 with a polymer/solids ratio of 0.15 . M8 also stands out with resistance close to $7 \mathrm{MPa}$ and the highest Quarry/solids ratio of 0.75 .

Figure 11 shows the increase in resistance as the age of the specimens increases, being in all cases M1 the best behavior reaching a resistance of $8 \mathrm{MPa}$ at the age of 28 days. A rapid increase in resistance is noted between the ages of 7 and 14 days. After 14 days, there is a gradual and slow increase of resistance until 28 days. Trend lines were annexed to Figure 11. The corresponding linear equations and the value of $R$ square of trend lines are shown in Table 4. The value of $R$ square shows that the values are attached to a straight line of trend with a deviation margin of less than $20 \%$ in most cases.

Compressive load [29] was applied at 14 days of age. Figure 12 includes only the samples of highest recorded load (M1, M3, M7, M8, and M11). The aforementioned specimens show cone-type fracture patterns, that is, cone well defined only at one end and vertical fractures through the cylindrical column (also called type two fractures). This fracture pattern is common and representative of cementing material. Only in M9, vertical fractures were formed across the ends, without welldefined cone formation or fracture type three. Figure 13 shows fractures at the age of 28 days of the specimens M1, M3, M5, M7, and M8, observing in all the cases conical fractures type two.

\section{Conclusions}

The waste derived from the Quarry stone was classified as inorganic low compressibility lime according the plasticity properties and grain-size distribution.

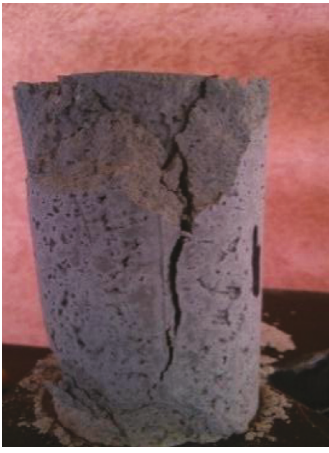

(a)

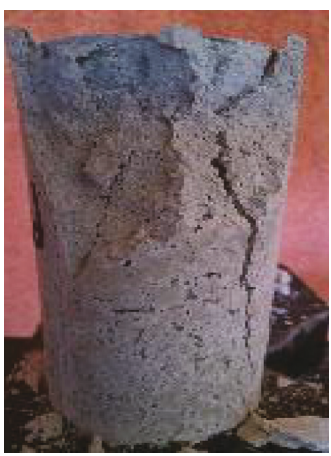

(c)

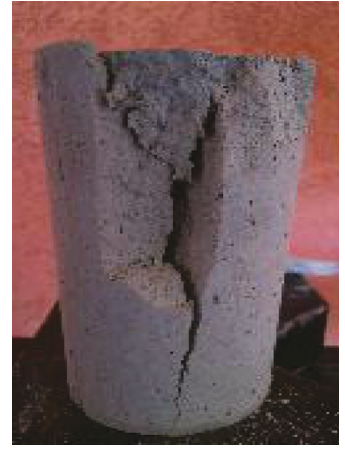

(b)

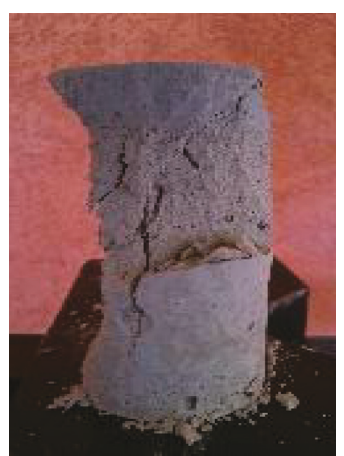

(d)

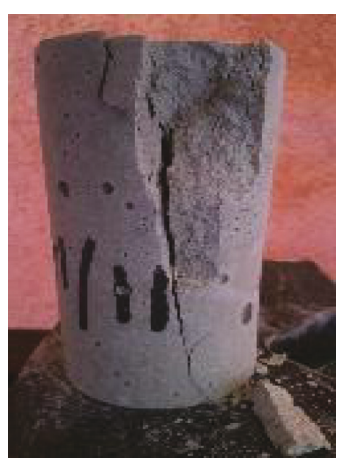

(e)

Figure 12: Types of fractures in samples at 14 days. Mixtures (a) M1, (b) M3, (c) M7, (d) M8, and (e) M11 with higher performance, respectively, from the left side (own source).

The geological analysis of the ignimbrite (Quarry stone) indicated that it contains lithic fragments of andesite, quartz, and feldspar in a vitreous matrix (lightly crushed vitreous fragments).

Based on the comparative analysis of the physicochemical characterization of the Quarry waste and various sands, it was observed that it could be viable to replace the sand by a fine aggregate by the similarity of chemical composition. The major component in the waste is silicon dioxide (76\%), and so it was considered pertinent to replace the content of sands that generally constitutes a mortar.

It is concluded that the polymeric material uses low amounts of cement with respect to the traditional mortar, and it is elaborated with the recycled quarry as they are presented in its granulometry, which saves the process of size selection. 


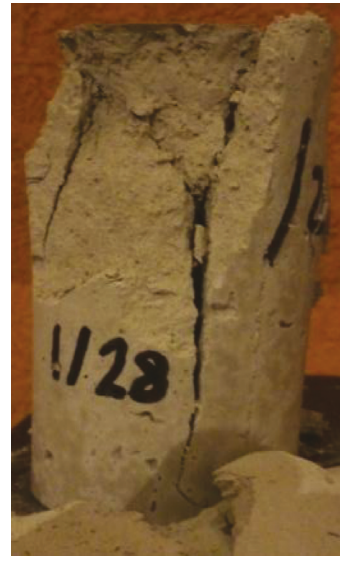

(a)

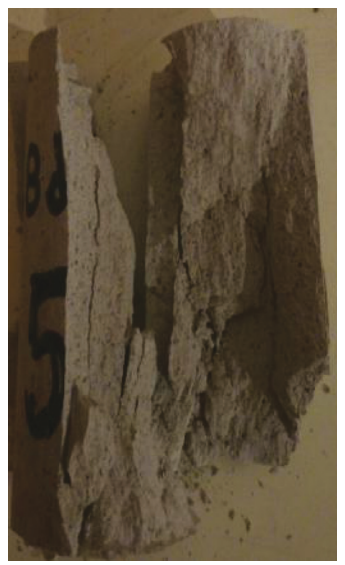

(c)

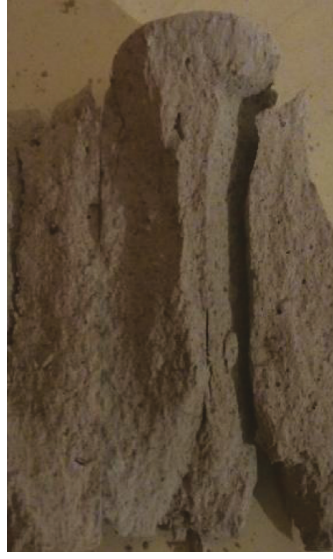

(b)

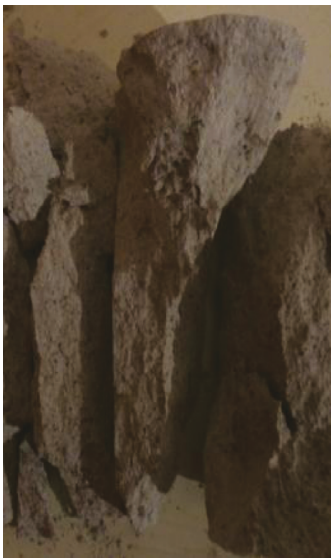

(d)

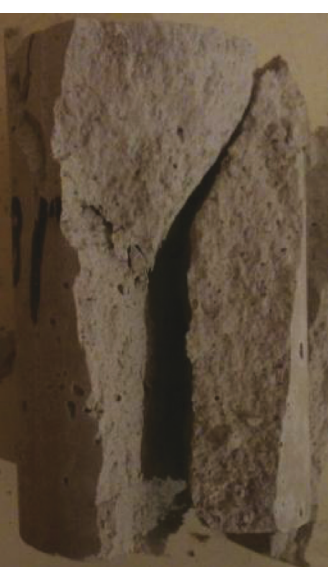

(e)

Figure 13: Types of fractures in 28-day samples. Mixtures (a) M1, (b) M3, (c) M5, (d) M7, and (e) M8 with higher performance, respectively, from the left side (own source).

According to the greater resistance obtained in the compression tests to specimens with age of 28 days, it is concluded that it is possible to replace the use of sand as fine aggregate by Quarry dust without significant reduction of the compressive strength of mortars.

The utilization of ignimbrite residues (Quarry waste) in the manufacture of mortars presents the best resistance to compression at 28 days of age with a resistance of $8 \mathrm{MPa}$ with the following optimum proportions: polymer/solids of 0.1 , water/solids of 0.3, and Quarry/solids of 0.67. Quantities greater than 0.15 of the polymer/solids ratio significantly decrease compressive strength [20]. Likewise, the compressive strength was considerably affected when quarry/solids ratios greater than 0.67 were used.

The polymer used in the mortar allowed a low water/solids ratio (0.3) and acceptable workability.

This strategy of reusing of ignimbrite waste has the advantage of using a large amount of these residues with respect to the amount of cement without using additional processes in the waste. The Quarry waste was used as it was collected directly from the deposits. This effective and sustainable solution is considered for the solid waste management of the Quarry industry and presents an alternative of raw material for the production of mortars.

\section{Conflicts of Interest}

The authors declare that they have no conflicts of interest.

\section{References}

[1] Servicio Geológico Mexicano, "gob.mx," August 2017, http:// mapserver.sgm.gob.mx/Cartas_Online/geologia/1653_F14C78_GM.pdf.

[2] Servicio Geológico Mexicano, "SGM," August 2017, http:// www.sgm.gob.mx/pdfs/HIDALGO.pdf.

[3] N. Almeida, F. Branco, J. de Brito, and J. R. Santos, "Highperformance concrete with recycled stone slurry," Cement and Concrete Research, vol. 37, no. 2, pp. 210-220, 2006.

[4] M. Galetakis and A. Soultana, "A review on the utilisation of quarry and ornamental stone industry fine by-products in the construction sector," Construction and Building Materials, vol. 105, pp. 769-781, 2015.

[5] A. K. Choudhary, J. N. Jha, K. S. Gill, and S. K. Shukla, "Utilization of fly ash and waste recycled product reinforced with plastic wastes as construction materials in flexible pavement," in Proceedings of the Geo Congress 2014, pp. 3890-3902, Atlanta, GA, USA, February 2014.

[6] G. Balamurugan and P. Perumal, "Behaviour of concrete on the use of quarry dust to replace sand-an experimental study," Engineering Science and Technology, vol. 3, no. 6, pp. 776-781, 2013.

[7] H. S. Sureshchandra, G. Sarangapani, and B. G. Naresh Kumar, "Experimental investigation on the effect of replacement of sand by quarry dust in hollow concrete block for different mix proportions," International Journal of Environmental Science and Development, vol. 5, no. 1, pp. 15-19, 2014.

[8] N. Arunachalam, V. Mahesh, P. Dileepkumar, and V. Sounder, "Development of innovative building blocks," Journal of Mechanical and Civil Engineering, vol. 1, no. 1, pp. 1-7, 2014.

[9] M. A. Q. Adajar, E. de Guzman, R. Ho, C. Palma Jr. III, and D. Sindico, "Utilization of aggregate quarry waste in construction industry," International Journal of GEOMATE, vol. 12, no. 31, pp. 16-22, 2017.

[10] T. K. Lohani, M. Padhi, K. P. Dash, and S. Jena, "Optimum utilization of Quarry dust as partial replacement of sand in concrete," International Journal of Applied Sciences and Engineering Research, vol. 1, no. 2, pp. 391-404, 2012. 
[11] M. Safiuddin, S. Raman, and M. Zain, "Utilization of quarry waste fine aggregate in concrete mixtures," Journal of Applied Sciences Research, vol. 3, no. 3, pp. 202-208, 2003.

[12] M. Galetakis, G. Alevizos, and K. Leventakis, "Evaluation of fine limestone quarry by-products, for the production of building elements," Construction and Building Materials, vol. 26, no. 1, pp. 122-130, 2012.

[13] R. Venkatakrishnaiah and P. Rajkumar, "Effect of quarry dust on waste plastic fiber reinforced concrete - an experimental study," Research in Civil and Environmental Engineering, vol. 1, no. 4, pp. 234-238, 2013.

[14] Y. Ohama, "Recent progress in concrete-polymer composites," Advanced Cement Based Materials, vol. 5, no. 2, pp. 31-40, 1997.

[15] L. Czarnecki, "Concrete-polymer composites: trends shaping the future," Journal of the Society of Materials Engineering for Resources of Japan, vol. 15, no. 1, pp. 1-5, 2007.

[16] M. Frigione, "Concrete with polymers," Eco-Efficient Concrete, pp. 386-436, Woodhead Publishing limited, Cambridge, UK, 2003.

[17] Y. Ohama, "Polymer based admixtures," Cement and Concrete Composites, vol. 20, no. 2-3, pp. 189-212, 1998.

[18] W. Meng, "Basic mechanical properties research of SAE latexmodified mortar," Advanced Materials Research, vol. 1088, pp. 621-625, 2015.

[19] S. R. Bothra and Y. M. Ghugal, "Polymer-modified concrete: review," International Journal of Research in Engineering and Technology, vol. 4, no. 4, pp. 845-848, 2015.

[20] Y. Ohama, Handbook of Polymer-Modified Concrete and Mortars, William Andrew Inc., Norwich, NY, USA, 1995.

[21] Y. Ohama, "Principle of latex modification and some typical properties of latex modified mortars and concretes," $A C I$ Materials Journal, vol. 84, no. 6, pp. 511-518, 1987.

[22] H. B. Wagner, "Polymer-modified hydraulic cements," Industrial and Engineering Chemistry, Product Research and Development, vol. 4, no. 3, pp. 191-196, 1965.

[23] L. K. Aggarwal, P. C. Thapliyal, and S. R. Karade, "Properties of polymer-modified mortars using epoxy and acrylic emulsions," Construction and Building Materials, vol. 21, no. 2, pp. 379-383, 2007.

[24] T. Fukuchi and Y. Ohama, "Process technology and properties of $2500 \mathrm{~kg} / \mathrm{cm} 2$ strenght polymer impregnated concrete," in Proceedings of the Second International Congress on Polymers in Concrete, D. W. Fowler and D. R. Paul, Eds., Polymers in Concrete, Austin, TX, USA, 45-56, 1978.

[25] P. M. Cabrera Castro and E. Beira Fontaine, "Geotechnical characterization of the experimental field at the civil engineering from the University of Oriente," Ingeniería, vol. 11, no. 2, pp. 57-66, 2007.

[26] ASTM, ASTM D422-63, Standard Test Method for ParticleSize Analysis of Soils, ASTM International, West Conshohocken, PA, USA, 2007.

[27] ASTM, ASTM Standard D 4318-10, Standard Test Methods for Liquid Limit, Plastic Limit, and Plasticity Index of Soils, Annual Book of ASTM Standards, West Conshohocken, PA, USA, 2010.

[28] ASTM Standard D 2487-93, Standard Test Method for Classification of Soils for Engineering Purposes, Annual Book of ASTM Standards, West Conshohocken, PA, USA, 1993.

[29] ASTM International, "Standard test method for compressive strength of cylindrical concrete specimens," March 2017, http://www.astm.org.

[30] M. Milán, C. Yañez, L. Navarro, S. P. Verma, and G. Carrasco Nuñez, "Geología y qeoquímica de elementos mayores de la
Caldera de Huichapan, Hidalgo, México," Geofísica Internacional, vol. 32, no. 2, pp. 261-276, 1993.

[31] A. Neville and J. J. Brooks, Tecnología del Concreto, Trillas, Mexico City, México, 2010.

[32] S. Valdés Constantino, "La Adición de Humo de Sílice para Concretos de Alta Resistencia," 2015.

[33] E. F. Irassar, V. L. Bonavetti, and G. Menéndez, "Cementos con material calcáreo: formación de thaumasita por ataque de sulfatos," Revista de la Construcción, vol. 9, no. 1, 2010.

[34] D. Laverde, J. Pedraza, S. Ospina et al., "El beneficio de arenas feldespáticas: una solución para la industria cerámica colombiana," Dyna, vol. 71, no. 143, pp. 45-54, 2004.

[35] G. del Carmen Tiburcio Munive, M. Sandez Aguilar, S. Aguayo Salinas, and D. BUrgos Flores, "Morteros para revestimiento de muros, utilizando arena zeolítica," Épsilon, vol. 1 , no. 10 , pp. 57-65, 2008.

[36] B. Bhardwaj and P. Kumar, "Waste foundry sand in concrete: a review," Construction and Building Materials, vol. 156, pp. 661-674, 2017.

[37] PINACAL, Planes de Competitividad Innovación y Entorno, Unión Europea, Valladolid, Spain, 2007.

[38] ASTM, ASTM C31/C31M-17, Standard Practice for Making and Curing Concrete Test Specimens in the Field, ASTM International, West Conshohocken, PA, USA, 2017. 


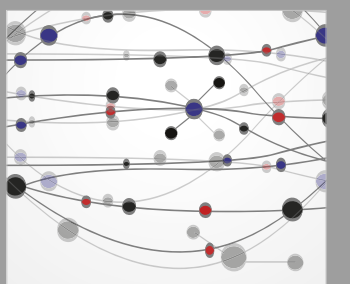

The Scientific World Journal
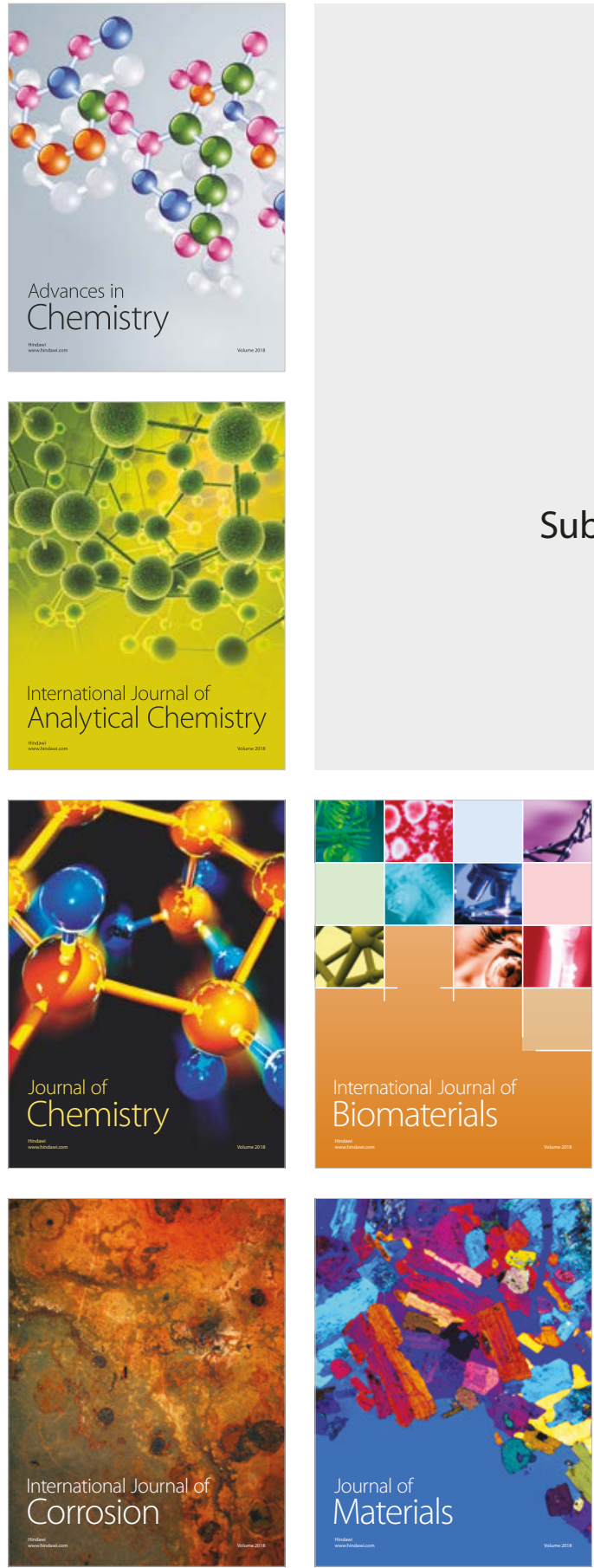

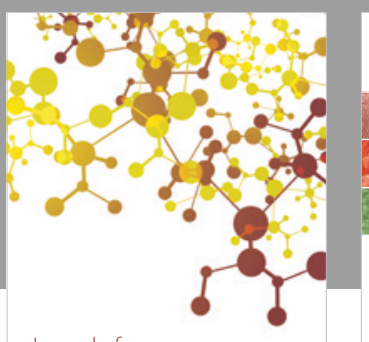

Journal of

Applied Chemistry
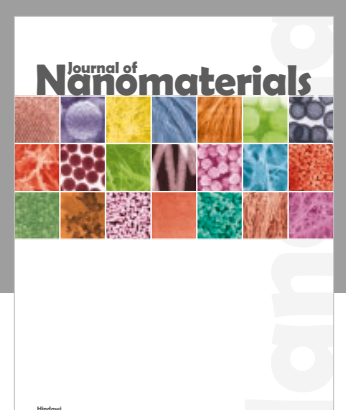

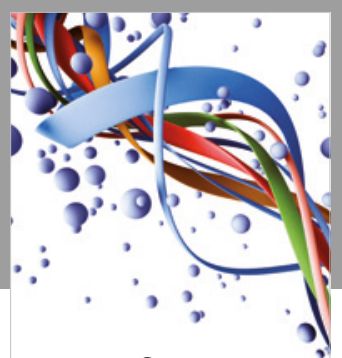

Scientifica

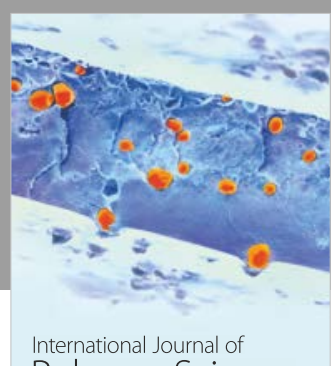

Polymer Science

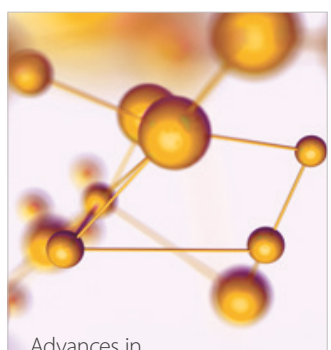

Physical Chemistry
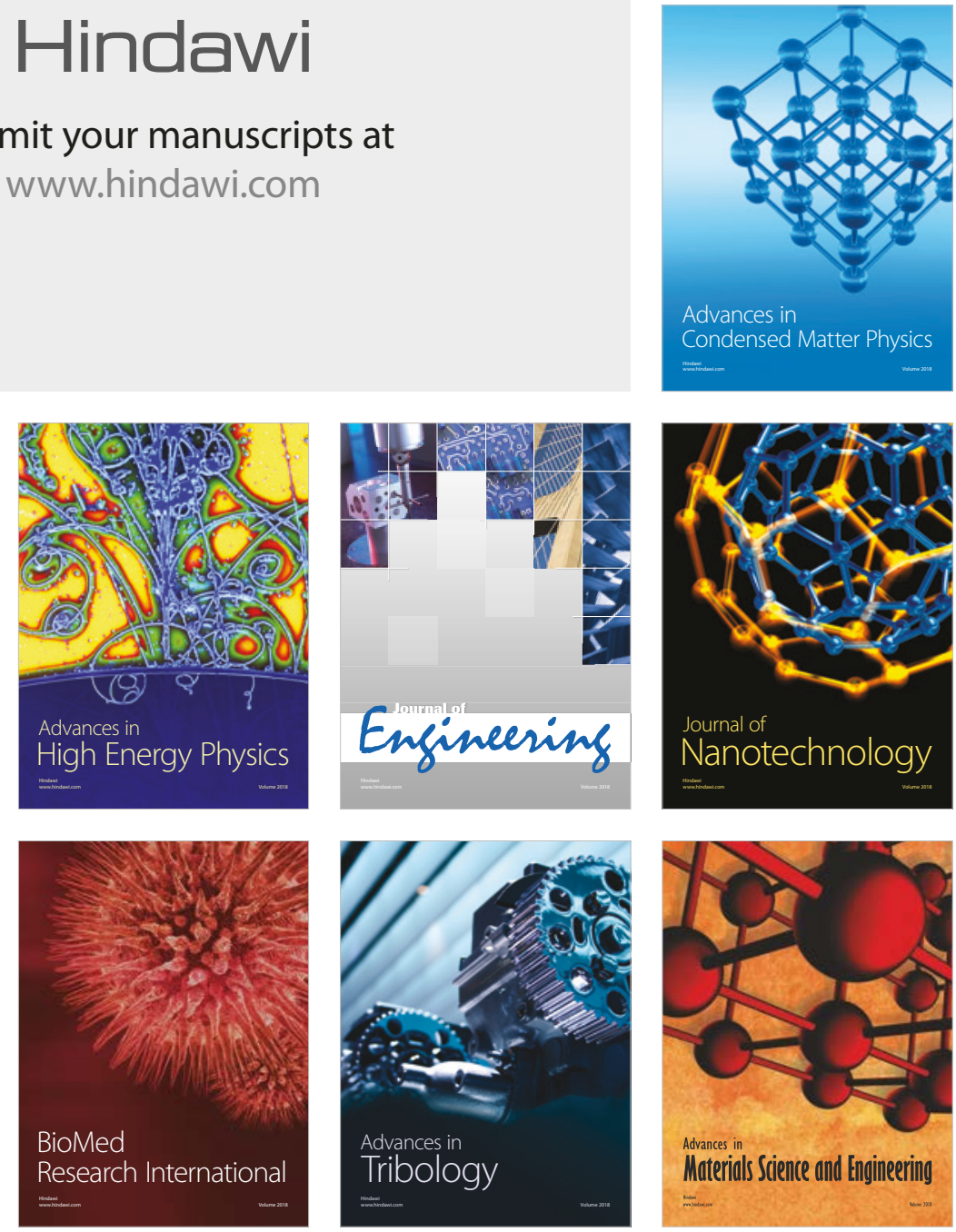